\title{
Model of Women Empowerment in Strengthening Family Socio-Economic Status
}

\author{
Isna Fitria Agustina ${ }^{1}$, Ilmi Usrotin Choiriyah ${ }^{2}$ \\ $\left\{\right.$ isnaagustina@umsida.ac.id $\left.{ }^{1}\right\}$ \\ Faculty of Social And Political Sciences, Universitas Muhammadiyah Sidoarjo ${ }^{1,2}$
}

\begin{abstract}
The Agropolitan Strategic Area of Sidoarjo Regency includes aquaculture areas along the east coast which covers six sub-districts. These areas have promising potential in agricultural production and management of certain natural resources, i.e. processed fish products and tourism. Regency Area Spatial Planning (RASP) of Sidoarjo 2009-2029, these strategic areas are made top priority and have significant influence towards economic growth, cultural and social environment in Sidoarjo Regency to increase welfare of society including women. The women hold a strategic role in the process of strengthening the economy and social life in their family.Women living in the coastal aquaculture has many outstanding contributions, including maintaining the stability of the economy, maintaining the availability of family food security, giving guarantee to the continuity of the children education and playing an active role in social life of the surroundings. The implementation of women's empowerment is conducted by increasing engagement and opening access of women in the process of awakening (change of mindset), the formation of the concept of the self-contained village, formation of cooperatives, family economic strengthening through training the skill in processing results of ponds, family financial management, parenting and the virtue of elementary education for their children.
\end{abstract}

Keywords: Women's Empowerment, Strengthening; Socio-Economic Status, Coastal, Agropolitan.

\section{Introduction}

The Agropolitan Strategic Area of Sidoarjo Regency has a potential fishery economy with a high growth rate, increasing from 15.043.326 kilos weight in 2013 to 15.277.288 kilos weight in 2014 [1]. The Minister of Marine and Fishery Decree No.39/Men/2011 issued on 21 July 2011 on the establishment of agropolitan area, Sidoarjo is established as a fishery area in an effort of distribute and accelerate development in addition to economy strengthening of particularly East Java fishery and marine [2]. It is also regulated in Sidoarjo Regency Local Regulation No.6 Year 2009 on Regency Area Spatial Planning (RASP) of Sidoarjo Year 2009-2029, Part Tenth of fishery agropolitan area Article 76, that the area consists of a number of villages in di Sedati, Buduran, Sidoarjo, Jabon, Candi, Porong dan Tanggulangin Sub-District. This east area of Sidoarjo Regency produces tiger shrimp and milkfish as its top commodity [3].

In agropolitan coastal areas, women specifically married women play an important role in maintaining the household income stability. A married woman is demanded to be productive in processing and managing local resources in order to assist her husband who works as a 
coastal-pond worker making a small amount of money. A woman also takes full responsibility of the social balance of her children's life in the environment they live in. Social interactions take place frequently while the husband is at work, a wife who is also a mother is expected to conform to the social norms.

\section{Result}

\subsection{Women Empowerment}

Women empowerment is a bottom-up transformation process of gender power relation which takes place at an individual level as well as a group as a result of the development of awareness about women subordination and the development of power to overcome it. The term empowerment has now been widely used by development agencies and in development documents in general but also in relation with women in particular [4]. Women become vital when they play double role in life which includes maintaining the sustainability of the family economy. This paper focuses on the women empowerment aspect in the effort of eradicating poverty in agropolitan strategic areas with a focus on the strengthening dimension of women's role through social and economic aspects which will take the fulfillment of family economic needs and the social role of women in those areas away from its current subordinate position.

\subsection{Family Socio-Economic}

[5] Social-economic is one's position in a society in relation to others' in terms of social environment, achievements, rights and obligations related to resources. [6] It is one's place or position in the human group which is determined by the type of economic activity, income, education level, housing type and office in an organization. [7] There are several factors deciding socio-economic condition, namely: (1). Education level, as education is an activity and effort to enhance personality by way of nurturing one's potentials i.e.: the spiritual (thinking, creativity, wills, feelings and consciousness) and the physical (senses and skills), (2). Income, it is the combined income of head of the family and its members in the form of money and goods, (3). Possessions over things or facilities, it is richness in the form of material goods which serve as means in running one's economy, (4). Type of housing, which includes the status of the house, the physical condition and the size.

\subsection{Agropolitan Area}

As described in Sidoarjo Regency Local Regulation No.6 Year 2009 on Sidoarjo Regency Spatial Planning Year 2009-2029, Agropolitan Area is an area consisting of one or more center of activities within a rural area as an agricultural production system and certain natural resources management made evident by an existence of a functional and hierarchical of a unifying space of a residential and an agrobusiness system. While in the agropolitan booklet [8] it is stated that Agropolitan is an agricultural city which grows and develops on an agricultural system and businesses and is capable of serving, stimulating, pulling and driving agricultural development activities in its surrounding areas.

[9] Stated that within agropolitan area, numerous services to support the sustainability of agrobusiness activities are made available. The service facilities include production means 
(fertilizers, seeds, medicine, equipment), production supports (banking, cooperatives, electricity), and marketing means (farmers market, stations, transportations). Therefore agropolitan contains a definition of the development of a particular area which is based on agriculture. Friedmann also stated that the character of agropolitan are: 1) the geographical scale is relatively small, 2) the planning and decision-making process is autonomous and independent in nature based on the participation of the locals, 3) the rural labor diversification is made on agricultural and non-agricultural sector, emphasizing on the growth of small industries, 4) an existence of functional relationship between the rural-urban industries and linkages and local economy resources, and 5) utilizing and enhancing local resources and technology.

\subsection{General Description of Kalialo Jabon}

The sub-district consists of 15 villages with a population of 55.228 or 13.894 Head of Family (HOF). A number of $2.265 \mathrm{HOF}$ is classified as Pre-Sufficient [10]. The majority of the population earn a living mainly as fish-farmers (fresh-water ponds and coastal ponds). Jabon Sub-District has some local resources not found in other sub-districts, namely: producing Gracelaria seaweed, milkfish, crab and tiger shrimp farmings, and sand-mining [11].

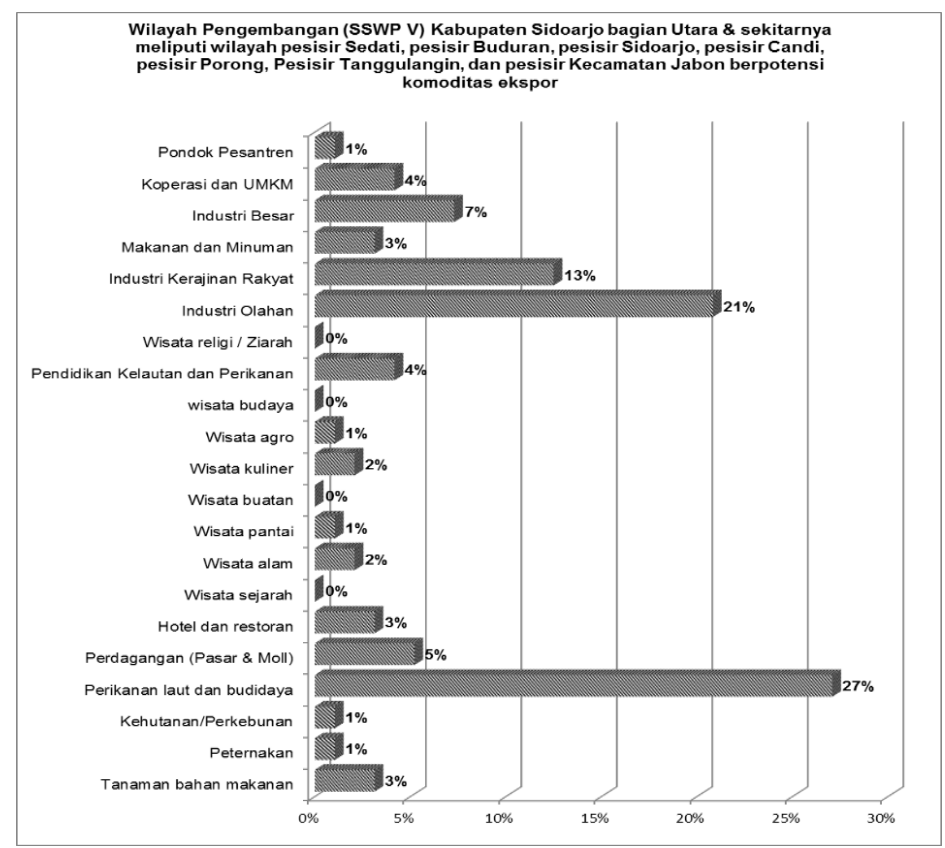

Fig. 1. Comodities of Sidoarjo Area

Jabon District, Sidoarjo District and Krian District are developed into one agricultural and fishery agropolitan strategic area in the interest of growing the economy, which is known as SIBORIAN (Sidoarjo-Jabon-Krian). The Agropolitan Area here is defined as an area consisting of one or more center of activities within a rural area as an agricultural production system and certain natural resources management made evident by an existence of a functional 
and hierarchical of a unifying space of a residential and an agrobusiness system. In accordance to Article 76 Part Tenth in the ASP, agricultural and fishery agropolitan area produces tigershrimp and milkfish as the top commodity. Other than assigned as agricultural and fishery agropolitan strategic area, Jabon District is made a top priority in clean water services which is included in the program of watering facilities network system and fishery area [12].

\subsection{Women Activities in Community Empowerment}

The concept of community empowerment includes the definition of community development and community based development, while community empowerment is the effort to improve all of a community members' worth and dignity including women's in order to free themselves from the trap of poverty and underdevelopment [13]. Community empowerment as the intentional effort to facilitate local communities in planning, deciding and managing the resources they have through collective action and networking so that they finally have the economic, ecological and social capabilities and independence [14]. Community-Based Forest Community Empowerment Model for Social-Anthropological Studies in Sidonganti Village Community, East Tuban Kerek District, they explained that empowerment is not only defined as participation and mobilization. Empowerment is more about enabling, empowering and protecting. An empowerment model which is not half-hearted in the surrounding area of a forest is conducted by increasing the villagers-based institutional strengthening as subjects as well as objects in the planning, executing and controlling the overall activities of the program. The stakeholders at different levels should play and commit to the role of facilitator, negotiator and motivator [15].

Five basic principles of community empowerment: 1). Community empowerment requires a break-even in each activity it manages although the orientation is different from a business organization as in community empowerment the profit gained is redistributed in the forms of other development programs or activities; 2). Community empowerment always involves the community participation in the planning and execution; 3). In implementing a community empowerment program, training activities is an inseparable element of physical development efforts; 4). In the implementation, an empowerment effort must be able to optimize resources particularly in terms of funding obtained from the government, private institutions and other sources; 5). Empowerment activities must be able to function as a liaison between the government interests which is macro in nature and the community interests which is macro [13].

Women empowerment seen from the socio and economic perspective plays a highly strategic role in agropolitan community. Women are known as persistent and resilient in doing things so the role an empowered women plays in her environment is essential. A woman who is a wife and a mother plays a role in improving her family socio-economic status and position as to create life enhancement. Community movement and participation from women have the ability to replace women's subordinate position with the position of women with competitive advantages. Women in general perform activities around their husbands' income-generating activities. Economy strengthening is done by producing processed products out of waste or using a portion of the husband catches, while social strengthening is done by maintaining the social norms. Thus women empowerment is performed by educational activities, trainings, guiding and institutional development to allow women a role in strengthening the family socio-economy. 


\subsection{Women Empowerment in Strengthening Family Socio-Economy in Agropolitan Area Kupang Village, Jabon Sub-District, Sidoarjo Regency}

Common problems in a coastal area community are; 1). Poverty, social inequality and continous economic strain, 2). Limited access to capital, technology and market which affect business dynamic, 3). Functional weakness of the existing socio-economic institutions, 4). Poor quality of human resources as a result of limited access to education, health and public services, 5). Degraded natural resources in coastal areas, the sea and small islands, and 6). Unestablished marine-oriented policies supposedly serving as the main pillar of national development[16]. Those are the problems faced by the coastal community in the East Coast of Jabon Sub-District, the limited waterways accessible to boats and pathways for bicycles and motorcycles, a distance of $3 \mathrm{kms}$ along the coastal ponds, while downtown Sidoarjo is $30 \mathrm{kms}$ away from the village, the poor condition of an insufficient number of health and education facilities. Such conditions would trigger hardship on the community economic development.

Local potential as coastal-ponds area, the majority of the population are pond-farmers and only a small number of the farmers own the ponds. In the marketing of the harvests they rely on middle-men who make the purchases directly after harvesting before any kind of processing so what happens is that the farmers make small amount of money [17]. Starting with the fore-mentioned conditions and being remote from adequate facilities and the far distance to the city, a number of women took the initiative to process a small portion of the harvest into processed food to add value. From each harvest, 5-10\% of it is processed into various kind if food [18]. Milkfish and shrimp are processed into nuggets, fish chips and the bones of the fish into calcium chip. A small portion of the Gracelaria seaweed harvest is processed into authentic snacks of traditional sweet and jelly.

In the implementation the empowerment is made possible by the collaboration with other parties who have successfully assisted the women of Kupang Village. Alligned with the basic principles of the concept of empowerment, Muhammadiyah University of Sidoarjo provides technical assistance in strengthening the socio-economy which initiated by the women of the village. The university students and lecturers regularly and continously provide technical assistance, in the economy side; in the form of trainings on healthy processed food, packaging and marketing the end products to strategic places. In the social side, the women are educated on how to make their village independent. Once the women are capable of assisting the husbands increasing their income by producing and selling processed food made of fish, they are inspired to build social power. Some activities are held for the purpose, in the field of environment and health; taking the form of building awareness on the importance of environment sustainability, develop habits of healthy lifestyle and the importance of sanitation, in the field of education; Socializing and held parenting trainings for mothers of school-aged children, socializing the importance of looking after children's psychology to raise healthy and happy children, socializing the importance 12-year compulsory education particularly elementary school-aged children.

The socio-economic strengthening of the women of Kupang Village did not stop there. They continue with activities which might be beyond the imagination of such remote community such as training on family finance, the formulation of self-sustained village and establishing a cooperative providing micro-loans. Slowly but surely they build independence as if to prove that women too are capable and have the power to contribute to the family economy and the maintenance of social stability. 


\section{Conclusion}

Women are key actors in household, women are the advocate of strengthening family economy and social life. Most women are capable of performing multiple roles to run her household, they have the ability to balance life and strive in any condition. The character is evident in their day-to-day life. The women of the coastal-ponds area of Kupang Village have made major contribution in strengthening the social and the economy. They are capable of maintaining the family economy stability, food availability and security, and have privileges to secure an education for their children and are ready to take an active role in the social life of the community they live in.

Acknowledgements. We hereby thank you to Universitas Muhammadiyah Sidoarjo for supporting the publication of this research.

\section{References}

[1] R. Ainur and et all, "Society Reception on the Marine Ecotoursm in Minneapolitan Region of Sidoarjo District," Asian J. Humanit. Soc. Stud., vol. 3, no. 5.

[2] "Keputusan Mentri Kelautan dan Perikanan," in Indonesia No.39/Men/2011, .

[3] P. K. Sidoarjo, "Peraturan Daerah Kabupaten Sidoarjo," in Nomor 6 Tahun 2009 Tentang Rencana Tata Ruang Wilayah Kabupaten Sidoarjo Tahun 2009-2029, .

[4] F. Genderpedia, "diakses,".

[5] "Hijriani Pradita Rahmah, Program Minapolitan pada Perkembangan Perikanan Tambak di Kabupaten Sidoarjo Tahun (2005-2015)," e-Journal Pendidik. Sej., vol. 6, no. 1, pp. 157-165.

[6] K. Heni, "Keadaan Sosial Ekonomi Orang Tua, www.dkampus.com, diakses tanggal.”.

[7] S. Abdulsyani, Skematika Teori dan Terapan. Jakarta: PT. Bumi Aksara.

[8] B.A.P.P.E.P.R.O.V., "Bookled Agropolitan." .

[9] H. A. A. Syahrani, "Penerapan Agropolitan dan Agrobisnis dalam Pembangunan Ekonomi Daerah.".

[10] Data, "Kecamatan Jabon dalam Angka."

[11] A. I. F, "Pengentasan Kemiskinan pada Masyarakat Pertambakan Sebagai Upaya Pengembangan Kawasan Strategis Agropolitan (Studi di Kecamatan Jabon Kabupaten Sidoarjo)," JKMP, vol. 2338 , no. 445 , pp. $75-88$.

[12] A. I. F., et all, and M. Kesempatan, "Sama dan Reproduksi Kesenjangan Sosial: Gambaran Nyata Kesenjangan Sosial dalam Pendidikan terhadap Anak-Anak Petani Tambak Pinggiran Sidoarjo," in Konferensi Nasional Kesejahteraan Sosial (KNKS) 2013, Surabaya.

[13] et all P. Mashudi, "Alleviation Based on Participatory Rural Appraisal in Sidoarjo Regency," $M I M B A R$, vol. 34 , no. 1, pp. 112-120.

[14] A. Rochmaniah, "Model Ekowisata Bahari Berbasis Pemberdayaan Masyarakat untuk Peningkatan ekonomi Lokal di Kawasan Strategis Pesisir di Kabupaten Sidoarjo," .

[15] H. Kusuma, "Model Pemberdayaan Perempuan Menuju Penguatan Ketahanan Pangan Keluarga Miskin Di Kesatuan Pemangku Hutan Ngawi," in Buku Kebijakan Pembangunan Gender: Kepemimpinan, Ekoloi, Kesehatan Reproduksi \& Seksual, Jakarta: ASWGI.

[16] K. Nelayan, Startegi Adaptasi dan Jaringan Sosial. Bandung: Humaniora Utama Press.

[17] K. Wachidah and et all. Pemberdayaan, "Masyarakat Pertambakan Melalui Program Posdaya di Kalialo Kecamatan Jabon Kabupaten Sidoarjo," .

[18] et all, "Symbolic Violence (Kekerasan Simbolik) Tengkulak Terhadap Komunitas Petani Tambak dan Reproduksi Kesenjangan Sosial di Daerah Pertambakan Jabon Sidoarjo,”. 